\title{
ROLE OF ISAAA IN THE IMPLEMENTATION OF BIOTECHNOLOGY: CHALLENGES AND OPPORTUNITIES FOR THE ISAAA AFRICENTER
}

\author{
F. WAMBUGU \\ ISAAA AfriCenter \\ P.O. Box 25171, Nairobi, Kenya
}

\begin{abstract}
ISAAA's primary goal is to facilitate and encourage the safe transfer and application of appropriate proprietary applications of biotechnology from developed countries in the north for a more sustainable agriculture improvement in developing countries. Currently, the ISAAA AfriCenter is involved in the development of bamana tissue culture, forest biodiversity conservation, pyrethrum rapid in vito micropropagation, fruit tree improvements and root and tuber crops.
\end{abstract}

Key Words: Biodiversity, biotechnologies, tissue culture

\section{RESUME}

Le but principal de l'ISAAA est de faciliter et d'encourager l'échange et le transfert sans risque, des biotechnologies appropriees des pays développés du nord pour l'amélioration de l'agriculture des pays en voie de développement. Actuellement, I'ISAAA Africenter s'est engagé dans le développement et la commercialisation des biotechnologies pour la culture tissulaire de la banane, l'amélioration de la chnne à sucre, la préservation de la biodiversité forestière et la micropropagation rapide du pyrèthre et des plantes à racines et turbecules in vitro.

Mots Cles: Biodiversité, biotechnologies, culture tissulaire

\section{INTRODUCTION}

The strategy of the International Service for the Acquisition of Agri-biotech Application (ISAAA) calls for the establishment of a total of six centre nodes. The AmeriCenter is located at Cornell University, USA, and the EuroCenter at the John Innes Centre in the UK. The AfriCenter was opened in July 1994 in Nairobi, Kenya and is hosted by the International Potato Centre (CIP). Plans are under way to establish additional centres in Latin America and Asia.
ISAAA's programme focuses on 12 countries: Indonesia, Malaysia, the Philippines, Thailand and Vietnam in Asia; Egypt, Kenya and Zimbabwe in Africa; and Brazil, Costa Rica, Argentina and Mexico in Latin America. A five step strategy includes: (1) assisting developing countries to identify biotechnology needs and priorities and to assess potential socio-economic impacts; (2) monitoring and evaluating availability of appropriate proprietary applications; (3) providing "honest broker" services matching needs and appropriate proprietary technologies; (4) 
mobilising funding from donor agencies to implement proposals; and (5) counselling developing countries on biosafety, biodiversity, food safety and intellectual property rights.

Although ISAAA is only a few years old, considerable progress has been achieved in terms of building a credible portfolio of projects, establishing nodes in the international biotechnology transfer network and broadening the institutional donor support group.

ISAAA's Projects. ISAAA now has six active projects that are aimed at demonstrating the feasibility of transferring proprietary biotechnology to developing countries. It is noteworthy that the first three projects brokered by-ISAAA have already delivered products ahead of schedule, thus demonstrating that scientists from developing countries can completely harness sophisticated biotechnology applications todeliver products in the short-term which can contribute to a more sustainable agriculture and a safer environment.

The potato project in Mexico has completed the initial training phase on biosafety requirements for field trials and transformation of three potato varieties (Alpha, Nortena, and Rosita). A visit by six potato growers was arranged to the different potato programmes in Maine, USA, to acquire new knowledge on multiplication of transgenic virus resistant potatoes. Large scale field trials are planned for 1995/96.

The second ISAAA project emphasized the development and use of a recombinant DNA (rDNA) based assay to detect black rot disease of crucifers. Researchers at Washington State University, USA, have almost perfected this assay. The training phase of this project has been implemented at both Washington State University and the Asian Vegetable Development Research Centre (AVRDC) in Taiwan.

The third project focused on development of native melons resistant to virus diseases in Costa Rica. A young Costa Rican scientist has now successfully accomplished the training at Asgrow Seed Co., USA. She successfully transformed one of the Asgrow melon lines with the cucumber mosaic virus (CMV) coat protein gene.

Researchers from Pioneer Seed Co., USA, and scientists from CNPMS-EMBRAPA in Sete
Lagoas, Brazil, have developed diagnostic kits for detection of two major viruses of importance in Brazil. The training phase of this project has now been completed in Brazil and USA.

The fifth project has achieved significant progress in the development of transgenic papaya cultivars with resistance to papaya ring spot virus for use in Brazil, Venezuela and Thailand. The training phase of the project is now in implementation at Cornell University.

The sixth project emphasises the development of transgenic insect resistant cotton cultivars for use in Brazil in collaboration with Monsanto, USA. Both Brazilian and Argentine cultivars have now been shipped to Monsanto for genetic engineering with the Bacillus thurigiensis (Bt) gene. In Zimbabwe, no full-pledged project has been implemented but the $B t$ protein has been tested for the major insect pests.

Future Plans. New activities planned by ISAAA include the opening of additional centres for better access and scope of coverage and action in areas associated with the acquisition and safe transfer of biotechnology applications. In addition to brokering projects for the new term delivery of improved and environmentally sustainable applications, food safety, socioeconomic analysis, and intellectual property rights are, new complimentary activities.

Financial Support. The donor support group for institutional funds now comprises 16 donors seven foundations, five bilaterals and four private sector companies. All four donors eligable for renewing their pledges have done so in 1995 indicating their satisfaction with progress and confidence in ISAAA's future activities.

\section{OPPORTUNITIES AND CHALLENGES FOR ISAAA AFRICENTER}

The experiences of the ISAAA AfriCenter are representative of the global perspective of developing nations, in agricultural development that is in the hands of the public, governmentowned research institutions with a few commercial-private initiatives, concentrating on the high-value exportable horticultural crops such 
as flowers, fruits, and vegetables. Government research institutions, probably due to limited funds and colonial legacy, invest more in the improvement of exportable cash crops such as coffee and tea, as compared to the food crops. It is against this background that biotechnologies for agricultural development must be transferred for application in developing countries.

However, interesting but not surprising is the considerable existence of developed tissue culture biotechnologies in local universities and agricultural research institutions. Even more encouraging is that the emerging biotechnologies are relevant to, and focused on the nceds of, the agricultural development of these countries. What seems to be lacking in all cases is a commercialisation phase; hence ISAAA's role in facilitating this phase is greatly required.

The commercialisation phase of locally developed and relevant biotechnologies needs clear understanding of existing barriers and devising strategies for overcoming them. For example, commercialisation barriers include lack of investment in the product development phase, lack of investment in the institutions necessary for commercialisation, lack of experienced personnel for commercial production and "wrong priorities" of investment in exportable cash crops versus food crops.

Considerable need exists in African and other developing nations to justify the transfer and application of new technologies to increase food and some industrial crops. For example, by the year 2000 , it is projected that serious food shortages will affect developing countries as populations continue to increase at a greater rate than food production. In Kenya for example, production of export crops continues to increase while production of food crops continues to decline. The horticultural crop export business is in the hands of about $20 \%$ of farmers, who have access to modern technologies. Meanwhile, $80 \%$ of the farmers are small-scale, but produce $60 \%$ of the food and have little or no access to modern technologies.

There are various opportunities and challenges for utilisation of agricultural biotechnology in the area of food crops (Altman and Raman, 1994; Wambugu, 1994). Examples include banana tissue culture for planting materials; root and tuber crops like potato, sweet potato and cassava for tissue culture virus elimination and rapid propagation (although there is the problem of reinfection): and gene technology for long-term sustenance in quality and productivity (disease and pest resistance).

Industrial crops such as sugarcane and cotton can benefit from gene technology to improve and increase productivity. Zimbabwe is interested in cotton Bigene technology in order to save money used to buy pesticides and for environmental health. The Pyrethrum Board of Kenya and the Kenya Agricultural Research Institute (KARI) are using tissue culture technology for increased productivity of pyrethrum. There are many opportunities in horticultural crops, fruits, flowers and vegetables for tissue culture. Other opportunities include reforestation, mainly using tissue culture for biodiversity conservation and commercial micropropagation and development of biofertilizers, such as rhizobium nitrogen fixers, as alternatives to imported fertilizer, wider usage of which leads to increased production and a healthy environment.

\section{SOME EXAMPLES OF PROJECTS THAT THE ISAAA AFRICENTER IS INVOLVED IN FACILITATING}

Banana is a staple crop diet in many parts of Kenya, and an important cash earner for the small scale farmers who market their produce in the nearby towns. Recently, the banana industry in Kenya has been devastated by Panama disease, Sigatoka leaf spot and weevil/nematode complexes. Lack of disease-free and disease resistant planting materials is threatening the food security of many families that depend on banana and has become a bottleneck in the expansion of banana production. In response to this need, KARI and Jomo Kenyatta University of Agriculture and Technology (JKUAT) have been collecting disease resistant banana varieties such as the cavendish type, in an attempt to rehabilitate the banana plantation. However, due to the great demand for bananas, currently estimated at $\mathbf{3 0}$ million planting suckers in Kenya, the effort had little success. The only way to restore and improve 
the banana industry in Kenya is by use of large scale rapid micropropagation (one to three million plantlets per year).

KARI, in collaboration with JKUAT, has developed successful banana tissue culture biotechnologies, and field tested with excellent performance and improvement over the traditional practice. However, they lacked large-scale commercial production and marketing experience, in micropropagation, which is not available in Kenya and most of Africa. In a joint effort between ISAAA and Agricultural Biotechnology for Sustainable Productivity (ABSP), Dr Esther Kahangi of the Department of Horticulture, JKUAT was sent to two companies one in the USA (DNA Plant Technologies Inc.) and Costa Rica (Agribiotechnologias de Costa Rica, SA), for training to gain commercial experience. Upon return, Dr Kahangi is supporting the banana industry in Kenya to meet local demand through local production initiatives.

Reforestation Project. This project has the potential for a major impact on Kenyan forestry efforts, especially for cypress reforestation after the cypress aphid epidemic of 1990, which devastated about 10 percent of all cypress forests in Kenya. This project addresses several needs, including biodiversity conservation, disease and pest control, and commercialisation through rapid in vitro micropropagation techniques of trees with high demand that cannot be met through traditional multiplication techniques. Three tree species have been identified: Grevillea robusta, eucalyptus and acacia. On this project, ISAAA is collaborating with Prof. Joe Mwangi, Director of the Forest Health Management Centre (FHMC).

Sugarcane Production. Kenya is a net importer of sugar as the rate of population increase in Kenya has overtaken sugarcane production and has created a market deficit. There is an urgent need for disease resistant, higher-yielding hybrids with higher sugar and low fibers content. Biotechnology can address some of these needs by increasing propagation rates, producing pathogen-free plants, introducing new clones, and reducing breeding time. ISAAA is considering a programme that will utilise developed biotechnologies for plant regeneration, including organogenesis, shoot tip culture rapid multiplication, and nodal cutting micropropagation to enhance introductions, breeding, and commercialisation that should finally increase production to meet market needs:

Ongoing Pyrethrum Rapid in vitro Micropropagation. Although there is a large market for Kenyan pyrethrum, lack of planting materials limits production and expansion. Eighty percent of total global pyrethrum is grown in Kenya by small scale farmers. A joint tissue culture programme with KARI and the Pyrethrum Board of Kenya started in 1987, and has produced more than one million disease and pest-free clones. ISAAA has been asked to support improvement of the production systems in the laboratory, to cut down on production costs and to increase overall efficiency in production of more pyrethrum plantlets to meet production and market demands.

Root and Tuber Crops Improvement. Tissue culture virus elimination micropropagation technologies, though not practiced on large scale, have failed to impact the potato seed industry in Kenya and many African countries due to notably high rates of re-infection. The potato seed industry faces serious seed degeneration problems especially due to virus diseases. Tissue culture technology would introduce gene-based virus resistance that could help farmers re-use their own seeds and also use lower altitudes for seed multiplication. Introduction of gene-based biotechnologies would be done through the proposed KARI Biotechnology Transfer Project, which for potato and sweet potato would work in collaboration with the regional office of the International Potato Centre (CIP). This project would concentrate only on the adaptation and application of gene technology transfer to local varieties and genotypes. It would start with potato, moving on to sweet potato transformation technologies, then addressing cassava, trying to adopt these biotechnologies to various African genotypes.

Private Biotechnology (Tissue Culture). This initiative needs to be encouraged and sustained to meet local demands, especially for planting materials for food crops such as banana and 
cassava. ISAAA is supporting two such small private laboratories in Zimbabwe which are locally owned: Brookeside Tissue Culture Laboratory and Agribiotech (Put) Ltd. Both laboratories need support in training personnel abroad and commercial production experience. Such private sector laboratories have a major role in multiplication and distribution of biolechnology products for commercialisation. However, public institutions and universities must be focused as centres of biotechnology transfer in order to reach the small scale farmer.

\section{ISAAA AND BIOTECHNOLOGY TRANSFER: CONTRIBUTING TO THE WELFARE OF FARMERS, CONSUMERS AND THE ENVIRONMENT}

The benefits and success of biotechnology and of ISAAA-facilitated biotechnology transfer will be measured in terms of increased production and income, more sustainable agriculture, and a safer environment initially through less dependency on pesticides. The following benefits can be realised through specific biotechnology applications:

Tissue Culture: Healthier germplasm with improved agronomic traits can increase productivity and production of food, feed, and fiber. Micropropagation will speed-up the developments of new and improved varieties of vagetatively propagated crops, allowing small farmers access to the benefits of improved germplasm. In forest products, it can contribute to biodiversity and acceleration of reforestation, which in turn, can contribute to the reduction of the greenhouse effect in the long term.

Diagnostics: Improved detection of diseases can lead to the more effective implementation of disease management programmes and facilitates implementation of integrated pest management. Together with meristem tip culture, healthier stock material of root and tuber crops and of vegetatively propagated crops (e.g. sugarcane and banana) can be produced.

Transgenics: Delivery of environmentally friendly and more durable resistance that will cater particularly to the needs of small farmers using appropriate delivery systems. This will result in decreased dependency on pesticides, more effective pest and disease control, and a more sustainable agriculture. Some of this technology is not only scale-neutral, but could provide relatively greater benefits to resource poor farmers who have benefited less, or have been precluded from technology transfer in the past.

Through access and adoption of the superior biotechnologies, developing countries can better compete wirh industrial coumtries for generating quality products for both domestic and export markets. The latter will generate foreign exchange.

Project Support Services: Assistance and counsel in biosafety, food safety, intellectual property rights and socioeconomic assessment will ensure that those agri-biotechnology products transferred to national programmes, farmers, and consumers will have been rigorously tested, and that client countries are well-versed in the complex area of intellectual property rights.

\section{REFERENCES}

Altman, D. and Raman, K.V. 1994. Biotechinology initiative to achieve plant pest and disease resistance. In: Plant Biotechnology Transfer to Developing Countries. Altman, D. and Watanabe, K. (Eds.), pp. 267-277. K.G.Landes Biomedical Publishers, Austin TX, USA.

Wambugu, F.M. 1994. Three year External and Internal Review: African Sweetpotato Virus Diseases Control and Biotechnology Transfer Project. Document reviews: Monsanto Company, St. Louis, USA. 
5 